\title{
Students' Perception on Ideal Age of Marriage and Childbearing
}

\author{
Mohanambehai Subranmiam, ${ }^{1}$ Kuswandewi Mutyara, ${ }^{2}$ Hanom Husni Syam ${ }^{3}$ \\ ${ }^{1}$ Faculty of Medicine Universitas Padjadjaran, ${ }^{2}$ Department of Public Health Faculty of Medicine, \\ Universitas Padjadjaran, ${ }^{3}$ Department of Obstetrics and Gynecology Faculty of Medicine \\ Universitas Padjadjaran Bandung/Dr. Hasan Sadikin General Hospital Bandung
}

\begin{abstract}
Background: Early-age marriage is still common in Indonesia, especially in the rural areas. There are many negative effects of the marriage; the young brides may get lower education, lower social status, minimum reproduction control, higher maternal mortality, higher domestic violence rate and others. Thus, this study is conducted to identify the students' perception on the ideal age of marriage and childbearing.

Methods: A cross-sectional descriptive study was conducted from June to September 2013 in Jatinangor using secondary data from Jatinangor Cohort Survey Team. The data comprised two hundred and twenty students from Jatinangor Senior High School and PGRI Vocational School. A hundred and ten males and a hundred and ten females were chosen by random sampling. Questionnaires were given after the written informed consent was obtained from the students.

Results: The results showed $74.55 \%$ of the students chose $19 \neg-24$ years old as the ideal age of marriage for a woman and $68.64 \%$ students chose 25-30 years old as the ideal age of marriage for a man. Moreover, for childbearing, 25-30 years old was chosen to be the ideal age for both man and woman. The percentage of students agreed to this was $74.55 \%$ and $54.09 \%$ respectively.

Conclusions: Majority of the students agreed on 19-24 years old and 25-30 years old as the ideal age of marriage for woman and man respectively. For childbearing, 25-30 years old was concluded as the ideal age for both genders. [AMJ.2015;2(4):591-6]
\end{abstract}

Keywords: Childbearing, early marriage, ideal age of marriage

\section{Introduction}

In recent years, a transition of marital age and childbearing has been drastically changing in many countries. The latest international statistics by World Health Organization $(\mathrm{WHO})^{1}$ indicated that more than 60 million women were married before the age of 18 . As it is narrowed down to Asian countries, half $(46 \%)$ of child marriages occur in South Asia. $^{2}$ In India ${ }^{3} 44.5 \%$ of women were married before the age of 18. Meanwhile, in Indonesia ${ }^{2}$ a survey conducted revealed $8.93 \%$ of married women were 15-19 years old. ${ }^{2}$ Subsequently, some of these brides in Indonesia had their first child by the age of 18 years old. ${ }^{4}$ It is one of the factors contributing to the high infant and maternal mortality. ${ }^{5}$ Currently, West Java has become one of the provinces that contribute to the high infant mortality rate in Indonesia. According to data from Child Health Program
Report of West Java Province Year 2010-2012, the number of neonatal deaths that were reported in West Java reached 3,624 and the infant mortality reached $4,650{ }^{6}$

Early marriages have negative effects on the young woman and her child. As an example, early motherhood has an increased likelihood of neonatal death and stillbirth, low birth weight infants, and child and infant morbidity and mortality. ${ }^{7}$ Furthermore, these young brides may also get lower education, lower social status at their in-law's place, minimum reproductive control, higher maternal mortality, higher domestic violence rate and others. ${ }^{8}$

Jatinangor where Universitas Padjadjaran is located is a highly populated area among west Java Province. It is dominated with young adult representing typical city in West Java which has a rapid development progress.

Due to the current global situation of

Correspondence: Mohanambehai Subranmiam, Faculty of Medicine, Universitas Padjadjaran, Jalan Raya BandungSumedang Km.21, Jatinangor, Sumedang, Indonesia, Phone: +6283821054454 Email: monas1991@yahoo.com 
changing marital age trends and the negative effects of early marriage, this study was conducted to find out the perception of students on the ideal age of marriage and childbearing in Jatinangor.

\section{Methods}

This was a cross-sectional descriptive study which was conducted from June to November 2013 in Jatinangor. The Secondary data obtained from Jatinangor Cohort Survey, Faculty of Medicine, Universitas Padjadjaran Indonesia, West Java, Indonesia were taken from the students of Senior High School and PGRI Vocational School in Jatinangor, Sumedang. The study was also approved by the Health Research Ethics Committee, Faculty of Medicine, Universitas Padjadjaran.

The samples were taken using cluster random sampling method from ten Senior High schools and Vocational schools in Jatinangor which reached a total of 3692 students. Through the method, two schools were selected which were Jatinangor Senior High School and PGRI Vocational School which had a total of 854 students. The Jatinangor Cohort Survey Team randomly selected students in the first and second year of schooling from the both of schools which made up 277 students. These students were then given an informed consent form to be filled up by their parents or guardian. The selection criteria were based on the students' willingness to participate in this study. The students who were absent on the day the data was taken and those who did not complete the questionnaire appropriately were excluded from the study. This presented a response rate of $81.5 \%$ which comprised one hundred and ten males and one hundred and ten females of PGRI Vocational School and Jatinangor Senior High School. They were used as the subjects of this study as they represented the school students.

After a brief introduction, they were given questionnaires which were validated by the Jatinangor Cohort Team to be filled up. The questionnaire consisted of two sections. The first section was on their personal details consisting of their name, gender, religion, date of birth, relationship status, race and their source of information about sex and child marriage. The second section was on the research topic which consisted of ten questions. These questions were related to their perception on ideal marital and childbearing age for male and female and also their reasons behind their answers. Data from the students were then inputted into the Windows Excel and classified into four age groups to identify the frequency for each question.

\section{Results}

The majority of the students were aged 16 years old and $99.1 \%$ of the samples are Muslims (Table 1). For the relationship status, the majority of the students said they have dated before but were not dating anyone currently. Apart from that, for the marital age of their parents, there was indication that $59.1 \%$ of the students' mothers got married at the age ranged from 19-24 years old. Meanwhile, $42.7 \%$ of the students' fathers got married at 25-30 years old. As for childbearing, $52.7 \%$ of their mothers and $56.8 \%$ of their fathers had their first child at the age of 25-30 years old (Table 2).

There was indication that majority $(74.6 \%)$ of the students chose 19-24 years old as the ideal age of marriage for a woman while $68.6 \%$ of students chose 25-30 years old as the ideal age of marriage for a man. Majority of the students chose 25-30 years old as the ideal age of marriage for both man and woman. This was indicated by a percentage of $54.1 \%$ for woman and $74.6 \%$ for man (Table 3 ).

Most students felt the main reason to get married and have a child was because adequate age had been reached (Table 4).

\section{Discussion}

This study depicts that both male and female students have perception 19-24 years old is

Table 1 Characteristic of Respondent

\begin{tabular}{lc}
\hline \multicolumn{1}{c}{ Characteristics } & n (\%) \\
\hline Age (years old) & $1(0.5)$ \\
14 & $35(15.9)$ \\
15 & $93(42.3)$ \\
16 & $63(28.6)$ \\
17 & $27(12.3)$ \\
18 & $1(0.5)$ \\
19 & \\
Religion & $218(99.1)$ \\
Muslim & $2(0.9)$ \\
Christian & $0(0)$ \\
Others &
\end{tabular}


Table 2 Relationship Status of Respondent

\begin{tabular}{lc}
\hline \multicolumn{1}{c}{ Relationship Status } & $\mathbf{n}(\%)$ \\
\hline Dated before & $137(62.3)$ \\
Yes & $83(37.7)$ \\
No & \\
Dating now & $107(48.6)$ \\
Yes & $113(51.4)$ \\
No & \\
Mother's Age of Marriage (years old) & $29(13.2)$ \\
$<18$ & $130(59.1)$ \\
$19-24$ & $22(10.0)$ \\
$25-30$ & $2(0.9)$ \\
$>30$ & $37(16.8)$ \\
Not sure & \\
Father's Age of Marriage (years old) & $2(0.9)$ \\
$<18$ & $87(39.5)$ \\
$19-24$ & $94(42.7)$ \\
$25-30$ & $0(0)$ \\
$>30$ & $37(16.8)$ \\
Not sure & \\
Mother's Age during First Childbirth (years old) & $2(0.9)$ \\
$<18$ & $116(52.7)$ \\
$19-24$ & $64(29.1)$ \\
$25-30$ & $0(0)$ \\
Not sure & $38(17.3)$ \\
Father's Age during First Childbirth (years old) & \\
$19-24$ & $2(0.9)$ \\
$25-30$ & $42(19.1)$ \\
Not sure & $125(56.8)$ \\
\hline & $13(5.9)$ \\
\hline & $38(17.3)$ \\
\hline &
\end{tabular}

the ideal age of marriage for woman. This was agreed by $164(74.6 \%)$ students. The reason given by majority of the students on the ideal marital age is because they perceive that adequate age has been reached to get married. This is due to the fact that the students are matured enough to know that a successful marriage requires a good balance between biological, psychological and sociological elements. Biologically, their sexual needs are fulfilled. Psychologically, mental maturity and emotional stability determines happiness in married life. Meanwhile, sociologically, marriage makes a pair of couple legitimate as married couples legally. ${ }^{9}$

On the other hand, below 18 years of age was the category least chosen by the students as the ideal age of marriage for a woman. Women of this age group are not prepared to start a family and they are still considered as a 
Table 3 Perception on Ideal Age Age of Marriage and Childbearing

\begin{tabular}{lcccccc}
\hline & \multicolumn{3}{c}{$\begin{array}{c}\text { Perception on ideal age of } \\
\text { marriage }\end{array}$} & \multicolumn{3}{c}{$\begin{array}{c}\text { Perception of ideal age of } \\
\text { childbearing }\end{array}$} \\
\cline { 2 - 7 } & $\begin{array}{c}\text { Male } \\
\text { n (\%) }\end{array}$ & $\begin{array}{c}\text { Female } \\
\text { n (\%) }\end{array}$ & $\begin{array}{c}\text { Total } \\
\text { n (\%) }\end{array}$ & $\begin{array}{c}\text { Male } \\
\text { n (\%) }\end{array}$ & $\begin{array}{c}\text { Female } \\
\text { n (\%) }\end{array}$ & $\begin{array}{c}\text { Total } \\
\text { n (\%) }\end{array}$ \\
\hline For Woman (years old) & & & & & & \\
$<18$ & $2(0.9)$ & $1(0.5)$ & $3(1.4)$ & $0(0)$ & $1(0.5)$ & $1(0.5)$ \\
$19-24$ & $84(38.2)$ & $80(36.4)$ & $164(74.6)$ & $52(23.6)$ & $43(19.6)$ & $95(43.2)$ \\
$25-30$ & $20(9.1)$ & $29(13.2)$ & $49(22.3)$ & $55(25.0)$ & $64(29.1)$ & $119(54.1)$ \\
$>30$ & $4(1.8)$ & $0(0)$ & $4(1.8)$ & $3(1.4)$ & $2(0.9)$ & $5(2.3)$ \\
For Man (years old) & & & & & & \\
$<18$ & $3(1.3)$ & $0(0)$ & $3(1.3)$ & $0(0)$ & $0(0)$ & $0(0)$ \\
$19-24$ & $(14.1)$ & $18(8.2)$ & $49(22.3)$ & $13(5.9)$ & $9(4.1)$ & $22(10.0)$ \\
$25-30$ & $67(30.5)$ & $84(38.2)$ & $151(68.6)$ & $78(35.5)$ & $86(39.1)$ & $164(74.6)$ \\
$>30$ & $9(4.1)$ & $8(3.6)$ & $17(7.7)$ & $19(8.6)$ & $15(6.8)$ & $34(15.5)$ \\
\hline
\end{tabular}

child. A similar study also shows that there is a higher rate of divorce among those who got married at this age due to lack of awareness to be responsible in married life. ${ }^{9}$ Moreover, these young brides may also get lower education, lower social status at their in-law's place, minimum reproductive control, higher maternal mortality, domestic violence rate and others. Younger marital age also poses an increased risk of sexually transmitted diseases in comparison with older ages. ${ }^{10}$

On the other hand, 25-30 years old was chosen to be the ideal marital age for a man by both the genders. This was agreed by $67(30.5 \%)$ male and $84(38.2 \%)$ female students. The reason that was given by majority of the students is because they think that the adequate age has been reached for a man to settle down and become more responsible, financially stable and is ready to start a family. Another study also shows there is a lack in emotional maturity among men who married early compared to the ones who married later ${ }^{11}$ More females agreed to this age group compared to males as women these days are generally more matured compared to men (Table 3). Therefore, they prefer an elder man to be their life partner. This also explains why no female agreed that below 18 years of age is the ideal age of marriage for a man.

Regarding the perception on the ideal age for a woman to have her first child, 55 male and 64 female students chose 25-30 years old as their age group of choice. At this range of age, the reproductive organs of a woman are ready to conceive and give birth as they are more physically and mentally prepared. Moreover, normal age pregnancy is considered a lowrisk situation compared to teenage pregnancy and elderly pregnancy in which increased

Table 4 Reasons for Ideal Age of Marriage and Childbearing

\begin{tabular}{lcc}
\hline \multicolumn{1}{c}{ Reasons } & $\begin{array}{c}\text { Marriage } \\
\text { n (\%) }\end{array}$ & $\begin{array}{c}\text { Childbearing } \\
\text { n (\%) }\end{array}$ \\
\hline Has reached the adequate age & $179(40.5)$ & $153(36.8)$ \\
Sufficient academic qualifications & $70(15.8)$ & $42(10.1)$ \\
Good for health & $50(11.3)$ & $57(13.7)$ \\
Already independent & $98(22.2)$ & $95(22.8)$ \\
Desire to start a family & $32(7.2)$ & $55(13.2)$ \\
No reason & $10(2.3)$ & $13(3.1)$ \\
Others & $3(0.7)$ & $1(0.2)$ \\
\hline
\end{tabular}


adverse obstetric and perinatal outcomes are faced. ${ }^{12}$ Besides that, only 1 female student agreed below 18 years of age was the ideal age for this matter. This age is unsuitable for childbearing as there are many maternal complications such as anemia, pregnancy induced hypertension, sexually transmitted diseases and premature labor and delivery. The most common complications concerning the infant are related to low birth weight, due to either prematurity or intrauterine growth restriction, infection, chemical dependence, sudden infant death syndrome, and increased morbidity and mortality during the first year. ${ }^{7}$

Furthermore, 5 students chose above 30 years old as the ideal age for a woman to have her first child. Late age of first childbearing are more prone of causing diabetes mellitus, antepartum hemorrhage, hypertensive disorder in pregnancy, cesarean section, abnormal fetal presentation and many more. ${ }^{12,13}$ Based on a research, delaying childbirth has significantly contributed to increasing rates of intrapartum primary cesarean delivery. ${ }^{14}$

The perception of students on the ideal age for man to have his first child was 25-30 years old. This was agreed by 164 students. According to many previous studies, this is said to be the ideal age as males will be in their reproductive peak and will be most fertile during this period. This is when a men's sperm has the highest quality and quantity. Therefore, they can produce healthy offspring with decreased risk of abnormalities. ${ }^{15}$ The age least agreed by the students were below 18 years of age. This is definitely not the ideal age to begin fatherhood as a man is not matured or prepared mentally, physically or emotionally to be a father. On the other hand, the evidence indicates that the offspring of older fathers have decreased fertility and an higher risk of birth defects, some cancers, and schizophrenia. ${ }^{16}$

Onasidenote, itwasfound certainlimitations while conducting this study. For example, while answering the questionnaires, there were a few respondents who were dishonest by copying their classmates' answers. Then, it was needed tighter supervision with the aid of the classroom teacher. Another hindrance was that the students were unable to understand the researcher's explanation regarding the aim of the questionnaire at times due to improper grammar and language use. To counter this, it is suggested an external translator or a local person to aid when the explanation session is conducted. After knowing the perception of students on marriage and childbearing age, further study can be conducted on the factors affecting the students' perception such as family background, education of parents and others.

In conclusion, the majority of the male and female students have perception that 19-24 years old is the ideal age of marriage for woman and 25-30 years old is the ideal age of marriage for man. Meanwhile, for age to have first child, 25-30 years old is perceived as the ideal age for both genders.

\section{References}

1. National Heart, Lung, and Blood Institute.1. WHO. Report No A65/13: early marriages, adolescent and young pregnancies. Geneva: WHO; 2012.

2. Jones GW. Asia Research Institute Working Paper Series No. 131: changing marriage patterns in Asia. Singapore: Asia Research Insitute \& Department of Sociology National University of Singapore;2010.

3. Raj A, Saggurti N, Balaiah D, Silverman JG. Prevalence of child marriage and its effect on fertility and fertility-control outcomes of young women in India: a cross-sectional, observational study. Lancet. 2009;373 (9678):1883-9.

4. Mukuria A, Aboulafia C, Themme A. The context of women's health: results from the demographic and health surveys, 1994-2001. Maryland: ORC Macro; 2005.

5. Raj A, Saggurti N, Winter M, Labonte A, Decker MR, Balaiah D et al. The effect of maternal child marriage on morbidity and mortality of children under 5 in India: cross sectional study of a nationally representative sample. BMJ. 2010;340:b4258.

6. UNPAD. Jawa Barat penyumbang terbesar angka kematian bayi di Indonesia 2012 [cited 2014 May 25]. Available from: http: / / www.unpad.ac.id / 2013/10/ jawa-barat-penyumbang-terbesar-angkakematian-bayi-di-indonesia/.

7. Malamitsi-Puchner A, Boutsikou $T$. Adolescent pregnancy and perinatal outcome. Pediatric endocrinology reviews. Pediatr Endocrinol Rev. 2006;(3 Suppl 1): 170-1.

8. Jensen R, Thornton R. Early female marriage in the developing world. Gender and Development. 2003;11(2):9-19.

9. Jannah USF. Pernikahan dini dan implikasinya terhadap kehidupan keluarga pada masyarakat madura 
(perspektif hukum dan gender). Egalita. 2012;7(1):83-101.

10. Kaestle CE, Halpern CT, Miller WC, Ford CA. Young age at first sexual intercourse and sexually transmitted infections in adolescents and young adults. Am J Epidemiol. 2005;161(8):774-80.

11. Khairani R, Putri DE. Perbedaan kematangan emosi pada pria dan wanita yang menikah muda. Jurnal Psikologi. 2008;1(2):136-9.

12. Suwannachat B, Ualalitchoowong $P$. Maternal age and pregnancy outcomes. Srinagarind Med J. 2007;22(4):401-7.

13. Joseph KS, Allen AC, Dodds L, Turner LA,
Scott H, Liston R. The perinatal effects of delayed childbearing. Obstet Gynecol. 2005;105(6):1410-8.

14. Smith GC, Cordeaux Y, White IR, Pasupathy D, Missfelder-Lobos H, Pell JP, et al. The effect of delaying childbirth on primary cesarean section rates. PLoS Med. 2008; 5(7):e144.

15. Sloter E, Schmid T, Marchetti F, Eskenazi B, Nath J, Wyrobek A. Quantitative effects of male age on sperm motion. Hum Reprod. 2006;21(11):2868-75.

16. Bray I, Gunnell D, Smith GD. Advanced paternal age: how old istoo old?.JEpidemiol Community Health. 2006;60(10):851-3. 